\title{
MORPHOLOGY OF FRUITS, DIASPORES, SEEDS, SEEDLINGS, AND SAPLINGS OF Syagrus coronata (Mart.) Becc.
}

\author{
MORFOLOGIA DE FRUTOS, DIÁSPOROS, SEMENTES, PLÂNTULAS E MUDAS DE \\ Syagrus coronata (Mart.) Becc
}

\section{Sueli da Silva SANTOS-MOURA ${ }^{1}$; Edilma Pereira GONÇALVES ${ }^{2}$; Luan Danilo Ferreira de Andrade MELO ${ }^{1}$; Larissa Guimarães PAIVA ${ }^{1}$; Tatiana Maria da SILVA ${ }^{1}$}

1. Master's in Agricultural Production by the Rural Federal University of Pernambuco, Academic Unit of Garanhuns, Garanhuns, PE, Brazil; 2. Teacher, doctor at the Federal Rural University of Pernambuco, Academic Unit of Garanhuns, Garanhuns, PE, Brazil.

\begin{abstract}
Licuri (Syagrus coronata (Mart.) Becc.) is an ornamental palm tree native of Brazil with great economic potential, because it provides raw material for manufacturing a wide range of products. The objective of this study was to assess the morphology of the fruits, diaspores, seeds, seedlings, and saplings of Syagrus coronata. The study was performed at the Laboratory of Seed Analysis (LSA) of the Federal Rural University of Pernambuco/Academic Unit of Garanhuns-PE, by using licuri fruits collected from the rural area of Caetés-PE. It was evaluated fruit morphology, diaspores, seeds, seedlings and saplings. Germination, in the form of cotyledon petiole emergence, began 15 days after sowing, is hypogeal, cryptocotylar, and remote tubular. It is slow and uneven, extending up to 60 days after the first eophyll appears. The saplings have alternate, pinnate, glabrous, entire leaves with parallel venation and sheath invagination. The primary roots persistent, the secondary roots arise from the stem root node in the primary root, and lateral roots only fasciculate was evidenced when the change was 300 days, and must remain in the nursery for at least 360 days after germination before taking it to the field, due to the slow development of this species.
\end{abstract}

KEYWORDS: Germination. Biometrics. Licuri. Oilseed.

\section{INTRODUCTION}

Palm trees belong to the Arecaceae (Palmae) family and consist of about 2,600 species in more than 240 genera. Brazil has the third most palm species diversity worldwide, with about 387 species and 37 genera of native palm trees, which have several uses (COSTA; MARCHI, 2008). They are widely exploited by local native communities living in the areas with the vegetative and reproductive parts are used, which demonstrates the nutritional, economic, and ecological importance of these species, in addition to their social value to different communities (OLIVEIRA et al., 2010).

Syagrus coronata (Mart.) Becc., commonly known as aricuri, licuri, licurizeiro, ouricuri, etc., is native to Brazil and of great economic importance. Its fruits are used as food and are consumed raw or as an ingredient in the manufacture of ice cream and juices. The nuts are used in the manufacture of coconut sweets, granola, and animal feed, while the endocarps are used to make high quality charcoal; these uses of have lowered the harvest of other endangered Brazilian tree species (CARVALHO et al., 2006; LORENZI et al., 2006).

The licuri plant grows well in the arid conditions of the Caatinga region, north of Minas
Gerais, which occupies the eastern and central portion of Bahia, Pernambuco, and the southern states of Sergipe and Alagoas (LORENZI et al., 2006). The management of these species is very important in these regions, some of which have restricted agriculture.

Literature on fruit and seed characteristics as well as native Brazilian palm tree seed germination processes is scarce. For example, the seeds of Syagrus coronata (Mart.) Becc are diverse in terms of their dispersal strategies. The study of seed morphology is an important tool for species identification (GROTH; LIBERAL, 1988) and also aids in seed germination research and test interpretation (ARAÚJO; MATOS, 1991; ARAUJO-NETO et al., 2002; ABUD et al., 2012).

Both the differences and similarities between plants are based on the morphological characteristics of the plant structural changes (CUNHA; FERREIRA, 2003). The morphological structures of fruits, seeds, and seedlings are important in the study of plant communities, for identification and differentiation of species, and for identification of plants in the field or their taxonomy.

The study of the morphological characteristics of young seedlings allows their 
identification in early developmental stages and permits the distinction of similar species. It also contributes to the study of natural regeneration and aids in the understanding of plant population dynamics and the identification of forest succession phases (DONADIO; DEMATTÊ, 2000; FERREIRA et al., 2001).

The diversity of palm tree species in Brazil, their potential use in energy production, and the lack of information on their morphology, germination, and seedling production underscore the need to develop and improve large-scale propagation techniques.

Our objective was to study the morphological characteristics of the fruits, diaspores, seeds, seedlings, and saplings of Syagrus coronata (Mart.) Becc.

\section{MATERIAL AND METHODS}

The study was conducted in the Laboratory of Seed Analysis (LSA) of the Federal Rural University of Pernambuco/Academic unit of Garanhuns-PE. Fruits of licuri were manually harvested from high-yielding trees in the rural region of Caetés City in the state of Pernambuco. One fruit cluster per tree was harvested using a trimmer. The fruits were then put in nylon bags and brought to the Laboratory of Seed Analyses for testing (described below).

\section{Morphology of fruits, diaspores, and seeds}

Dehiscence, color, persistent structures, shape, consistency, and quantity of seeds per fruit were analyzed. Endocarps were removed with a stone in order to extract the seeds. A knife blade was used to make longitudinal sections of the seeds and excise the embryos.

\section{Morphology of germination}

One hundred seeds were sown micropyle side down at a depth of $2 \mathrm{~cm}$ in vermiculite substrate in a polyethylene tray $(40 \times 30 \times 8 \mathrm{~cm})$ and stored in the laboratory. The substrate was moistened with distilled water to $60 \%$ retention capacity, according to the method of Brasil (2009).

Substrate moisture was maintained throughout the test and evaluations began on the $15^{\text {th }}$ day, when the cotyledon emerged, until the first eophyll appeared on the 60th day. After the onset of germination, observations were made daily and evaluations carried out as new structures appeared. Seedling growth and changes in root- and shoot color were also noted.

\section{Morphology of seedlings}

After 60 days, 12 seedlings were transplanted into plastic bags containing a mixture of sand, humus and cattle manure in a 2:3:1 ratio. The bags were placed in a nursery under a $50 \%$ light intensity. Seedlings were watered daily and all aspects of growth described and illustrated until the plants reached the fully expanded four-leaf stage at about day 360. Parameters studied included the number of leaves and their venation; development of primary, lateral, and secondary roots; development of leaves and stems; and development of root and leaf color. Sapling height (in centimeters) was measured using a ruler.

The identifications of the structures and the morphological description of the diaspores, seeds, germination, seedlings, and saplings of Syagrus coronata (Mart.) Becc. were performed in a manner similar to that by Damião-Filho (2004), Ferreira (2005), Henderson (2006), and Lopes (2007). Illustrations were made by freehand drawings and by photography.

\section{RESULTS AND DISCUSSION}

The fruit of Syagrus coronata (Mart.) Becc is a fleshy drupe whose color varies from light to dark green when immature and yellow or orange when ripe. Usually this color change begins at the base of the fruit and extends to the apex. The fruits are mainly monospermic (rarely dispermic), with different sizes and shapes. The base of the fruit may be flat, rounded, or truncated. The apex is palmate, rounded, or pointed. Because of these variations, the fruit may be globular, ovoid or ellipsoidal (Figure 1A). The perianth and stigma are grayish and brownish, respectively, remaining in the fruit until maturity. This property is common to the taxon, as observed for Attalea maripa (Aubl.) Mart by Araújo et al. (2000); Bactris gasipaes Kunth (FERREIRA, 2005); Oenocarpus minor Mart. (MENDONÇA et al., 2008); and Butia capitata (Mart.) Beccari (MOURA et al., 2010).

The fruit is divided into three distinct layers: exocarp, mesocarp, and endocarp, which together form the pericarp (Figure 1B).The exocarp is fibrous, smooth, and hairless, with a rust-colored spot in the apical region (Figure 1A). This is a prominent feature in immature fruits. Araújo et al. (2000) found similar rust-colored spots covering almost the entire fruit of Attalea maripa (Aubl.) Mart.

The ripe mesocarp is yellow or orange, mucilaginous and fibrous (Figure 1A). The endocarp is woody, brownish, and variable in shape 
and size, ranging from globular to ellipsoid. Mesocarp fibers are distributed along its surface, concentrating around the three basal pores (Figure $1 \mathrm{~B}$ and 1C). The presence and longitudinal distribution of these fibers were identified by Araújo et al. (2000) in Attalea maripa (Aubl.) Mart. and Euterpe precatoria Mart. (AGUIAR; MENDONÇA, 2003).

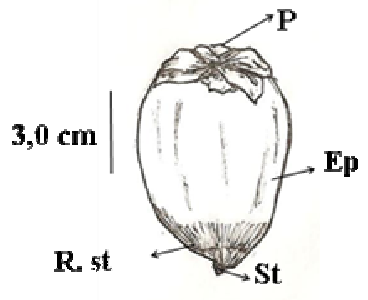

A

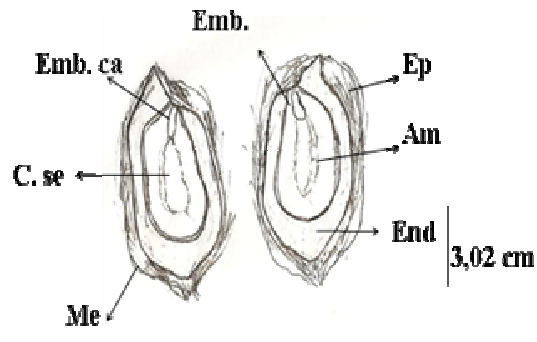

B

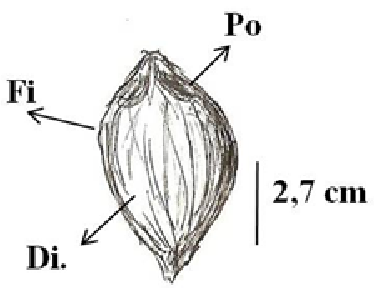

C

Figure 1: Morphology of fruit of Syagrus coronata (Mart.) Becc. Entire fruit (A) Longitudinal section of the fruit (B), Diaspore (C). Perianth (p), Rusty stain (R. st), Stigma (St), Epicarp (Ep), Mesocarp (Me), Diaspore (Di), Embryo (Emb), Cavity of the embryo. (C. emb), Almond (Am), Cavity almond (C. am), Fibers (Fi), Pore (Po).

The seed minus the endocarp measures approximately $1.5 \mathrm{~cm}$ in length, varying in shape from round to ovoid. It is brownish and has a fine to rough texture with narrow branching raphe that run from the top to the base where the micropyle is located (Figure 2A). Araújo et al. (2000) identified the presence of grooves, raphe, and operculum in the seed of Attalea maripa (Aubl.) Mart, but these structures strongly adhered to the endocarp. Internally the seed is solid, thick, rich in oil and white, turning silver with age. It occupies a large space in the endocarp and has a protruding inner cavity (Figure 2B), unlike the seed cavity of Euterpe precatoria Mart. observed by Aguiar and Mendonça (2003).
The embryo is small, approximately $0.3 \mathrm{~cm}$ long, and $0.10 \mathrm{~cm}$ in diameter. It is located at the base of the endosperm below the micropyle. It is oriented towards one of the pores present in the basal part of the endocarp. It is white in the apical part and yellow in the basal part. It has two distinct regions: one proximal, facing the micropyle, and from which the cotyledon petiole will emerge; the other is distal and corresponds to the future haustoria that will develop as the shaft grows (Figure 2A-C). These two regions were also observed by Ferreira (2005) during the seed germination of Bactris gasipaes Kunth and by Oliveira et al. (2010) in Oenocarpus minor Mart embryo.

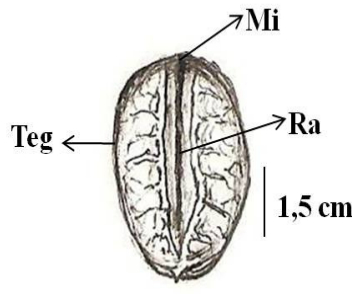

A

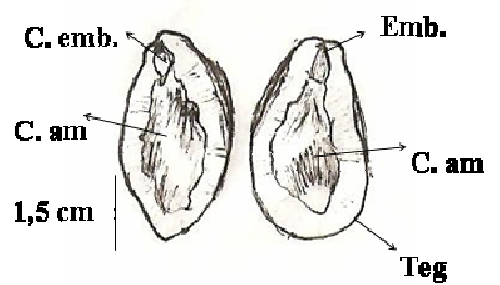

B

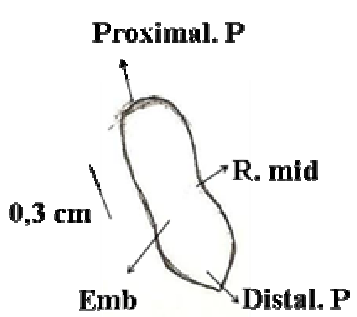

C

Figure 2: Morphology of seed of Syagrus coronata (Mart.) Becc. Seed (A), Longitudinal section of the seed (B), Embryo (C). Micropyle (Mi), Tegument (Teg), Raphe (Ra), Embryo cavity (Emb. ca), Embryo (Emb.) Cavity of the seed (C. se), Proximal part (Proximal. P), Region Mid (R. mid), Distal part (Distal. p). 
The difference between these two regions of the embryo of licuri seeds is clearly visible due to the slight narrowing of its median part. The proximal portion is cylindrical, however, and the most distal portion is rounded (Figure 2C). Overall, the embryo of palm seeds is conical, cylindrical or ovoid, undivided, and small relative to the size of the whole seed.

The shape and size of the embryo as well as the position it occupies in the endosperm are quite varied in palm seeds. The Oenocarpus minor Mart. embryo is located at the center of the basal region of the seed, measuring an average of $9 \mathrm{~mm}$ long and 4 $\mathrm{mm}$ in diameter (OLIVEIRA et al., 2010). The embryo of Syagrus oleracea (Mart.) Becc. is described by Batista et al. (2011) as lateral, peripheral, straight, and poorly differentiated, approximately $2.76 \mathrm{~mm}$ long, with a central ridge where the primary root emerges.

Syagrus coronata (Mart.) Becc, began germinating 15 days after sowing and was characterized by the growth of the cotyledon petiole, a yellow-white cylindrical structure resembling a primary root and containing the embryo axis (Figure 3A-C), called by Damião-Filho (2005) referred to it as the embryophore. The germination process is slow and uneven. The germination rate is $10 \%$ at 15 days after sowing (at this stage the cotyledon petiole is differentiated) and $30 \%$ at 60 days.

Thirty days after germination, the cotyledon petiole is yellowish and about $7 \mathrm{~cm}$ long. At this stage, the cotyledon petiole has small dots on its base, about the same color as the root. It is here where the initial differentiation of primary root and lateral roots occurs (Figure 3C). At forty-five days, the primary, lateral, and plumular roots are differentiated, they are similar in color. The root base narrows and separates the seedling into the root and shoot. A longitudinal slot emerges above the root base, followed by an elongated yellow-white cataphyll with a pointed apex (Figure 3D-E). It has an apical opening from which a similarly colored second cataphyll emerges. At ground level, the second cataphyll is green, has a pointed apex, and is more elongated than the first cataphyll (Figure 3F). The first two cataphylls are modified leaves devoid of limbo. The first eophyll is embedded, and at this stage, the cotyledon petiole and the root measure approximately $10 \mathrm{~cm}$. The lateral roots are more developed and are similar in color to the primary root, but are still very small.
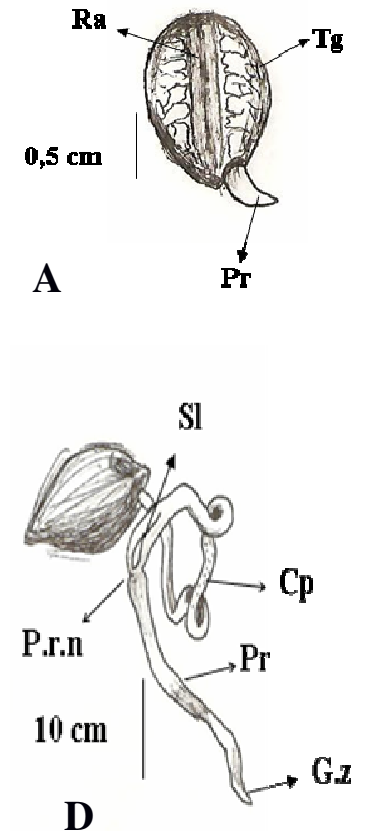

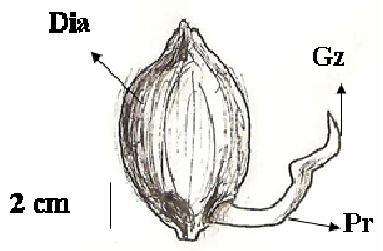

B

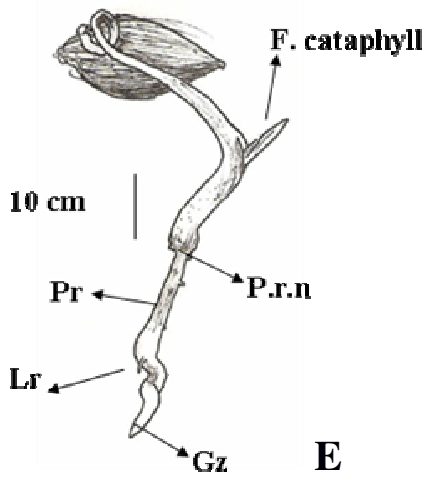

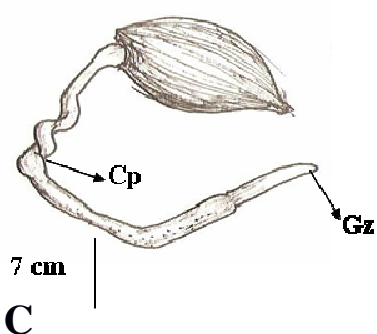

S. cataphyll

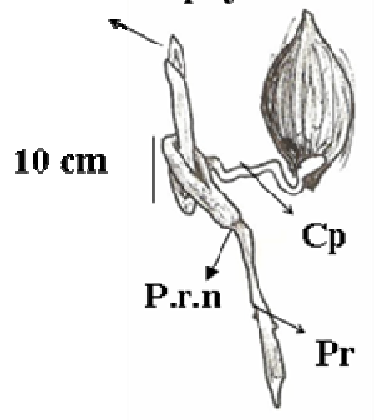

$\mathbf{F}$

Figure 3: Stages of germination and seedling development of Syagrus coronata (Mart.) Becc., at 15 (A and B), 30 (C) and 45 days (D-F). Raphe (Ra), Tegument (Tg), Diaspore (Dia), Cotyledon petiole (Cp), Slot (SI), Primary root (Pr), Plumular root node (P.r.n), First cataphyll (F.cataphyll), Second cataphyll (S.cataphyll), Lateral root (RI), Growth zone $(\mathbf{G z})$. 
At 60 days the first leaf develops. Because of the slow and uneven seed germination of this species, the seedlings are at different stages. In some, the first eophyll is still closed; in others, they are expanded (Figure 4A-C). The first eophyll is dark green, full, linear, lanceolata, and has an acute apex. The primary root is yellowish, strong and persistent, and the lateral roots are simple, short, and similar in color to the primary root (Figure 4D). At this stage, the plantlets are approximately 11 to 13 $\mathrm{cm}$ long, lateral roots and root hairs are more developed. The cotyledon petiole and the endocarp adhere to the seedling, which, at this stage, still depends upon the food reserves contained within the seed.

Germination is remote tubular, so-called because the embryo axis develops at a distance from the seed, beyond the open sheath cotyledon stem base. The germination is cryptocotyledonary since the leaf blade remains in the cotyledon. The seed is hypogeal because the cotyledon petiole and the seeds stay below the substrate during germination (Figure 4 A-D). Henderson (2006) classified the germination of palm seeds into three types: tubular remote, ligular remote, and ligular adjacent, while Costa and Marchi (2008) mentioned only two types: adjacent and remote.

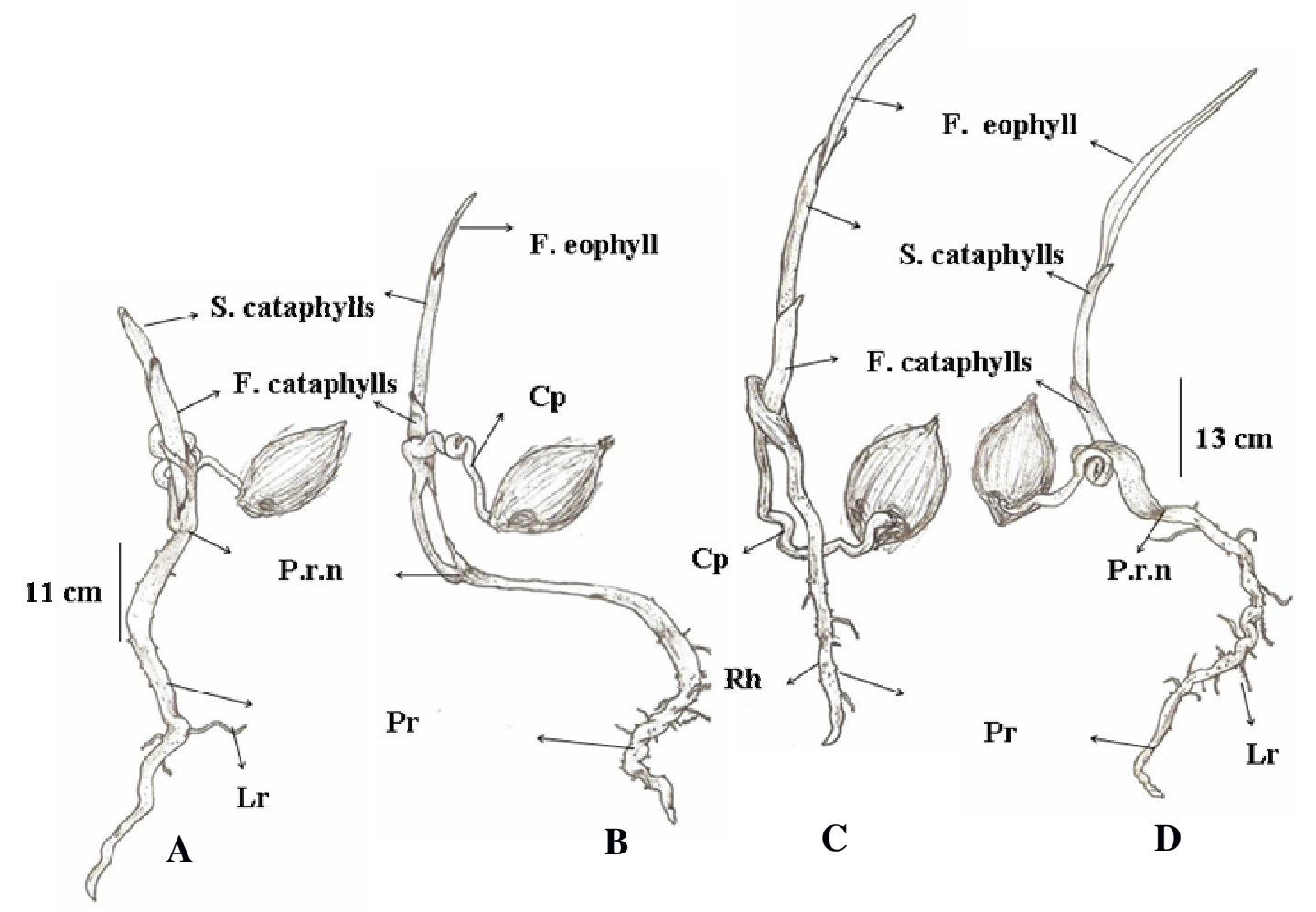

Figure 4: Morphology of germination of Syagrus coronata (Mart.) Becc. at 60 days. First cataphyll (F. cataphylls), Second cataphyll (S. cataphylls), Plumular root node (P.r.n), Primary root (Pr), Lateral roots (Lr), Cotyledon petiole (C.p), Root hairs $(\mathbf{R h})$, First eophyll (F. eophyll), Lateral roots (RI), Closed cataphylls (A), Closed eophylls (B and C), Expanded eophyll (D).

The germinations of seeds Syagrus oleracea (Mart.) Becc. (BATISTA et al., 2011), Phoenix dactylifera (DAMIÃO-FILHO, 2005; HENDERSON, 2006), and Caryota mitis Lour. (CARVALHO; AOYAMA, 2007) were also described as remote tubular. Luz et al. (2012) classified Archontophoenix cunninghamii H. Wendl. seed germination as ligular adjacent. Thus, it is essential to study seedling morphology in early developmental stages. Germination and morphological changes may be either quite different among species and characteristic of each one or common among species within the same family.

Figure 5 shows the morphological characteristics of licuri seedlings 360 days after germination. Growth is very slow; at 180 days, the plant measures approximately $18 \mathrm{~cm}$. At this stage, the two leaves are fully expanded, glabrous, and dark green. The first leaf is thin, lanceolate, pointed, and has parallel ribs. The second leaf is the widest at its base and narrows toward the apex, giving it a pinnate shape. The ribs are thin and parallel, while 
the cotyledon petiole, diaspores, and two cataphylls are dry, but remain attached to the plant (Figure 5A). At 180 days, the primary root is well developed, has fine lateral roots, and a thin and elongated root system. Both the primary and lateral roots, which were cream yellow, are light brown. Dense root hairs, the same shade as the roots themselves, are randomly distributed on both the mature and younger roots (Figure 5A-B).

One-year-old licuri seedlings have four leaves and an average height of $25 \mathrm{~cm}$. At this stage,

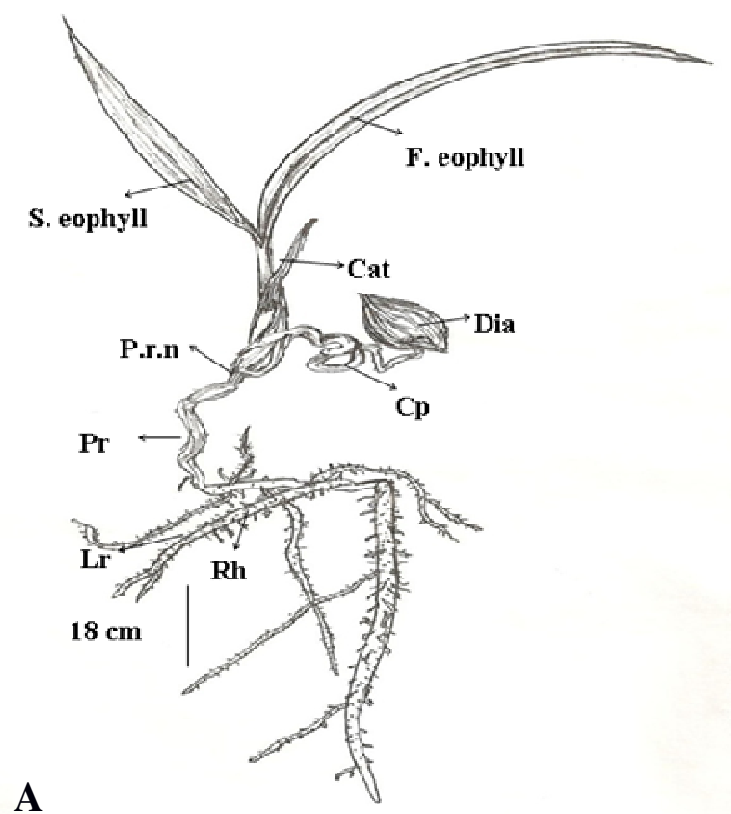

SANTOS-MOURA, S. S. et al.

new structures have emerged (Figure 5B). The fascicular root system is well developed and the secondary roots grow laterally to the primary root, arising from the plumular root node. The root system is at first yellow, and as it matures, it becomes brownish, thick, strong, and cylindrical, with a pointed growing region (Figure 5B). These are more developed in the lateral roots than they are in the primary root, whose growth is reduced as both lateral roots and root hairs develop, as can be seen in Figure 5B.

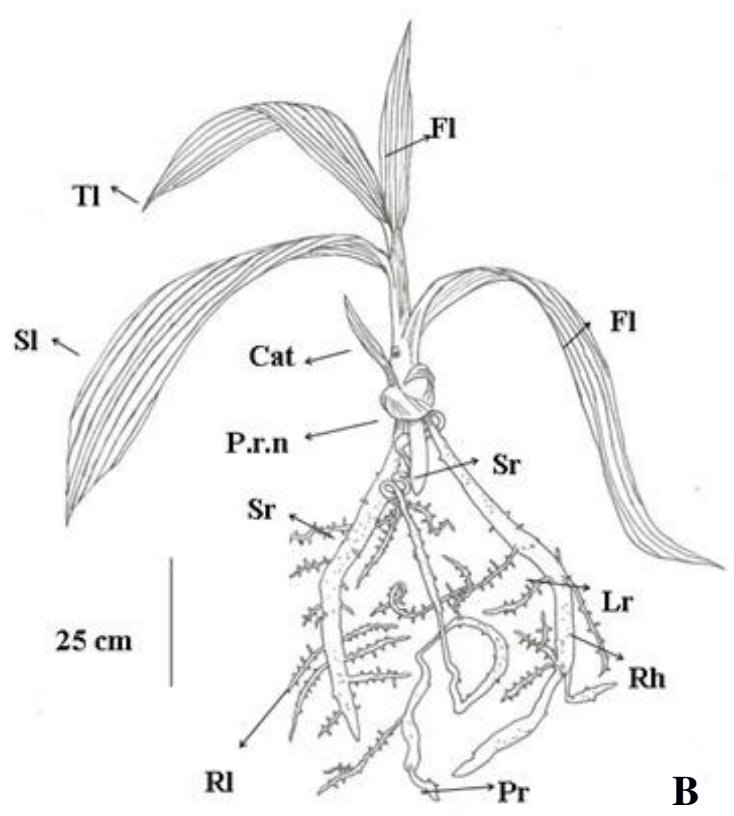

Figure 5. Morphology changes in Syagrus coronata (Mart.) Becc seedlings at 180 (A) and 360 days (B), after sowing. First eophyll (F. eophyll), Second eophyll (S. eophyll), Cataphyll (Cat), Diaspore (Dia), Cotyledon petiole $(\mathbf{C p})$, Primary root $(\mathbf{P r})$, Lateral roots $(\mathbf{L r}$, Secondary roots $(\mathbf{S r})$, Root hairs $(\mathbf{R h})$, Plumular root node (P.r.n), First leaf (Fl), Second leaf (SI), Third leaf (TI), Fourth leaf (Fl), and Fourth leaf(Fl).

The younger leaves are a deep green and have alternate phyllotaxis, broad limbo, whole, pointed apices, and wide ribs which are very prominent and parallel to the longitudinal direction (Figure 5B). These characteristics differ from those of the adult plant leaves, which are distributed in the spiral along the stem, limbo parted, and have thin leaflets inserted along the axis of the midrib.

Palm trees are monocots and have fascicular root systems. In the early development of licuri seedlings, however, the root is well developed and strong, remaining on the plant for one year. This is a characteristic feature of seedlings raised from seeds with remote germination (Figure 5A-B). The development of the primary root of Syagrus coronata seedlings (Mart.) Becc is a survival mechanism of the species; it is adapted to harsh climatic conditions. The plants tend to settle in the field before the shoot reaches the soil surface.

The morphological characteristics of the seedlings indicate that 360 days is an ideal nursery residence time for them. At this stage, the plant has well-developed leaves and root system which will help ensure greater resistance and chances of survival. Nevertheless, after comparing the growth of this species in different shading conditions, Carvalho et al. (2006) proposed that 18 months is the ideal age to transplant it, since it is at that time the plants establish and can be managed best in the field.

The morphologies of the fruit, diaspores, seed germination, and seedling of the perennial oilseed Syagrus coronata (Mart.) Becc have specific characteristics, which facilitate its recognition and 
identification in the laboratory and in the field. They also aid in the understanding of its biological cycle, natural regeneration, management, and conservation strategies.

\section{CONCLUSIONS}

The fruits of Syagrus coronata (Mart.) Becc) are green when immature and yellow or orange when ripe. They have perianths and persistent stigma, and their oil seeds are brownish with prominent raphe. The embryos are inserted into the base of the endosperm just below the micropyle. They are small, have an indefinite shape and two distinct regions, proximal to and distal from the
SANTOS-MOURA, S. S. et al.

micropyle. The proximal region is cylindrical and the distal is round.

Germination is hypogeal, cryptocotylar, and remote tubular, begins at 15 days after sowing, and is marked by the protrusion of the cotyledon petiole. Germination is slow and non-uniform, extending to 60 days after sowing, at which time the first eophyll emerges.

The seedlings grow slowly, and have persistent and well developed primary roots. A fascicular root system appears at 300 days and secondary roots develop from the plumular root node. Because of the slow development of this species, seedling nursery residence time should be at least 360 days before field transplantation.

RESUMO: O licuri (Syagrus coronata (Mart.) Becc.) é uma palmeira ornamental, nativa do Brasil, de grande importância econômica, pois fornece matéria prima para confecção de diversos produtos. Assim objetivou-se estudar a morfologia de frutos, diásporos, sementes, plântulas e mudas de $S$. coronata. O trabalho foi realizado no Laboratório de Análise de Sementes - (LAS) da Universidade Federal Rural de Pernambuco/Unidade Acadêmica de Garanhuns-PE, com frutos de licuri coletados na zona rural de Caetés-PE. As avaliações realizadas foram: morfologia de frutos, diásporos, sementes, plântulas e mudas. A germinação se inicia aos 15 dias após a semeadura com a protrusão do pecíolo cotiledonar, é hipógea, criptocotiledonar do tipo remota tubular, lenta e desuniforme, estendendo-se até os 60 dias quando ocorre a emissão do primeiro eófilo. A muda possui folhas alternas, com limbo inteiro, glabras, coloração verde e nervuras paralelas, pinadas, com bainha invaginante, a raiz primaria é persistente, as raízes secundárias surgem a partir do nó caulinar radicular na lateral da raiz primária e o sistema radicular fasciculado só foi evidenciado quando a muda estava com 300 dias, e deve permanecer no viveiro no mínimo de 360 dias após a germinação antes de levá-la ao campo, em função do lento desenvolvimento da espécie.

PALAVRAS-CHAVE: Germinação. Biometria. Licuri. Oleaginosa.

\section{REFERÊNCIAS}

ABUD, H. F.; GONÇALVES, N. R.; PEREIRA, M. S.; PEREIRA, D. S.; REIS, R. G. E.; BEZERRA, A. M. E. Germination and morphological characterization of the fruits, seeds, and seedlings of Pilosocereus gounellei. Brazilian Journal of Botany, São Paulo, v. 35, n. 1, p. 11-16, 2012. http://dx.doi.org/10.1590/S180699592012000100003

AGUIAR, M. O.; MENDONÇA, M. S. Morfo-anatomia da semente de Euterpe precatoria Mart. (Palmae). Revista Brasileira de Sementes, Pelotas, v. 25, n. 1, p. 37-42, 2003. http://dx.doi.org/10.1590/S010131222003000100007

ARAÚJO, M.G.P.; LEITÃO, A.M.; MENDONÇA, M.S. Morfologia do fruto e da semente de inajá (Attalea maripa (Aubl.) Mart.) - Palmae. Revista Brasileira de Sementes, Londrina, v. 22, n. 2, p. 31-38, 2000. http://dx.doi.org/10.17801/0101-3122/rbs.v22n2p31-38

ARAÚJO, S.S.; MATOS, V.P. Morfologia de sementes e de plântulas de Cassia fistula L. Revista Árvore, Viçosa, v.15, n.13, p.217-230, 1991.

ARAÚJO-NETO, J. C.; AGUIAR, I. B.; FERREIRA, V. M.; PAULA, R. C. Caracterização morfológica de frutos e sementes e desenvolvimento pós-seminal de monjoleiro (Acacia polyphylla DC.). Revista Brasileira de Sementes, Londrina, v. 24, n. 1, p. 203-211, 2002. 
BATISTA, G. S.; COSTA, R. S.; GIMENES, R.; PIVETTA, K. F. L.; MÔRO, F. V. Aspectos morfológicos dos diásporos e das plântulas de Syagrus oleracea (Mart.) Becc - Arecaceae. Comunicata Scientiae, Teresina, v. 2, n. 3, p. 170-176, 2011.

BRASIL. Regras para Análise de Sementes. Ministério da Agricultura, Pecuária e Abastecimento. Secretaria de Defesa Agropecuária. Brasília. MAPA/ACS, 2009. 395p.

CARVALHO, P. C.; AOYAMA, E. M. Morfologia de frutos, sementes, plântulas e germinação de Caryota mitis Lour (Arecaceae). Revista de Biociência, Taubaté, v. 13, n. 3-4, p. 148-155, 2007.

CARVALHO, N. O. S.; PELACANI, C. R.; RODRIGUES, M. O. S.; CREPALDI, I. C. Crescimento inicial de plantas de licuri (Syagrus coronata (Mart.) Becc.) em diferentes níveis de luminosidade. Revista Árvore, Viçosa, v. 30, n. 3, p. 351-357, 2006.

COSTA, C. J.; MARCHI, E. C. S. Germinação de sementes de palmeiras com potencial para produção de agroenergia, Informativo Abrates, Londrina, v. 18, n. 1,2,3, p. 039-050, 2008.

CUNHA, M. C. L.; FERREIRA, R. A. Aspectos morfológicos da semente e do desenvolvimento da planta jovem de Amburana cearensis (Arr. Cam.) A. C. Smith -cumaru - Leguminosae Papilionoideae. Revista Brasileira de Sementes, Pelotas, v. 25, n. 2, p. 89-96, 2003. http://dx.doi.org/10.1590/S010131222003000400013

DAMIÃO-FILHO, C. F. Morfologia vegetal. 2ed. Revisada e ampliada. Jaboticabal: FUNEP, 2005. 172p.

DONADIO, N. M. M.; DEMATTÊ, M. E. S. P. Morfologia de frutos, sementes e plântulas de canafístula (Peltophorum dubium (Spreng.) Taub.) e jacarandá-da-bahia (Dalbergia nigra (Vell.) Fr.All. ex Benth.). Fabaceae. Revista Brasileira de Sementes, Londrina, v. 22, n. 1, p. 64-73, 2000. http://dx.doi.org/10.17801/0101-3122/rbs.v22n1p64-73

FERREIRA, R. A.; BOTELHO, S. A.; DAVIDE, A. C.; MALAVASI, M. M. Morfologia de frutos, sementes, plântulas e plantas jovens de Dimorphandra mollis Benth. - faveira (Leguminosae-Caesalpinioideae). Revista Brasileira de Botânica, São Paulo, v. 24, n. 3, p. 303-309, 2001. http://dx.doi.org/10.1590/s010084042001000300009

FERREIRA, S. A. N. Pupunha, Bactris gasipaes Kunth in: FERRAZ, I. D. K.; CAMARGO, J. L. C. (Eds), Manual de Sementes da Amazônia. Fascículo 5, 12p. INPA, Manaus, Brasil. 2005.

GROTH, D.; LIBERAL, O.H.T. Catálogo de identificação de sementes. Campinas: Fundação Cargil, 1988. $182 \mathrm{p}$.

HENDERSON, F. M. Morphology and anatomy of palm seedlings. The Botanical Review, New York, v. 72 , n. 4, p. 273-329, 2006. http://dx.doi.org/10.1663/0006-8101(2006)72[273:MAAOPS]2.0.CO;2

LORENZI, H.; SARTORI, S. F.; BACHER, L. B.; LACERDA, M. T. C. Frutas brasileiras e exóticas cultivadas: de consumo in natura. Instituto Plantarum de Estudo da Flora, São Paulo: Nova Odessa, 2006. 640 .

LOPES, V.S. Morfologia e fenologia reprodutiva do ariri (Syagrus vagans (Bondar) Hawkes) - Arecaceae - numa área de caatinga do município de senhor do Bonfim-BA. 2007. 87f. Dissertação (Mestrado em Agronomia) - Universidade Federal da Paraíba, Paraíba, 2007.

LUZ, P. B.; PIVETTA, K. F. L.; NEVES, L.G.; PAIVA SOBRINHO, S.; BARELLI, M. A. A. Caracterização morfológica do diásporo e da plântula de Archontophoenix cunninghamii (Arecaceae). Comunicata Scientiae, Piauí, v. 3, n. 4, p. 244-248, 2012. 
MENDONÇA, M. S.; OLIVEIRA, A. B.; ARAÚJO, M. G. P.; ARAÚJO, L. M. Morfo-anatomia do fruto e semente de Oenocarpus minor Mart. (Arecaceae). Revista Brasileira de Sementes, Lavras, v. 30, n. 1, p. 90$95,2008$.

MOURA, R. C., LOPES, P. S. N., BRANDÃO JUNIOR, D. S., GOMES, J. G.; PEREIRA, M. B. Biometria de frutos e sementes de Butia capitata (Mart.) Beccari (Arecaceae), em vegetação natural no Norte de Minas Gerais, Brasil. Biota Neotropical, Campinas, v. 10, n. 2, p. 416-410, 2010. http://dx.doi.org/10.1590/s167606032010000200040

OLIVEIRA, A. B.; MENDONÇA, M. S.; ARAÚJO, M. G. P. Aspectos anatômicos do embrião e desenvolvimento inicial de Oenocarpus minor Mart.: uma palmeira da Amazônia. Acta Botanica Brasílica, São Paulo, v. 24, n. 1, p. 20-24, 2010. http://dx.doi.org/10.1590/S0102-33062010000100003 